\title{
ANALISIS SEMIOTIKA NILAI GOTONG ROYONG TAYANGAN BOCAH PETUALANG DI TELEVISI TRANS 7 (Analisis Semiotika Roland Barthes Dalam Tayangan Bolang Edisi Kabupaten Lahat Sumatera Selatan)
}

Oleh:

\author{
DORI DRAMIKA, SRI NARTI, HARIUS EKO SAPUTRA \\ Program Studi Ilmu Komunikasi Fakultas Ilmu-Ilmu Sosial \\ Universitas Dehasen Bengkulu
}

\begin{abstract}
This study to detennine the meaning contained in the show adventurous child edition of Labat Regency South Sumatra on Television. The research method used in this research is semiotic analysis method using semiotik analysis of roland barthes. Divided by the meaning of denotation, connotation and myth. The analysis shows that there is meaning of semiotic analysis according to Roland Barthes. The Meaning of Denotation on the show of Bocah Petualang The edition of Labat regency of South Sumatra is the location where they are shooting is an unspoiled forest seen from the number of green trees that grows flourish and shade. The river is still Asri and not contaminated by the number of fish catches. Meaning of connotation in the show Bocah Petualang Edition of Labat regency of South Sumatra is to explain that children who are very devoted to their parents and also loyal friends. Myths in the show Bocah Petualang The edition of Labat regency of South Sumatra is a smoke that can make bees become tame and not bite. Ash which can make Rang-Rang ants become tame and does not bite. And Reverse the clothes that can make someone fmd a way out when lost. The myth is merely a belief that is believed to be descended only but as human beings we may believe it may not. Value gotong royong contained in the show Bocah Adventurers Edition of Labat regency of South Sumatra is the Children who always together mutually help-help to fmish a job together.
\end{abstract}

\section{Keywords: analysis of semiotika, value of gotong royong, adventurous boy}

\section{PENDAHULUAN}

Televisi adalah salah satu jenis media massa elektronik yang bersifat audio visual, direct dan dapat membentuk sikap. Televisi berasal dari kata tele dan vision, yang mempunyai arti masingmasing jauh (tele) dari bahasa Yunani dan tampak (vision) dari bahasa Latin. Jadi, televisi berarti tampak atau dapat melihat jarak jauh beragam tayangan mulai dari hiburan sampai ilmu pengetahuan ada dalam televisi, adanya beragam channel televisi membuat masyarakat memiliki banyak pilihan untuk menyaksikan tayangan berkualitas (Ardianto : 2007:13).

Fungsi Televisi sama dengan fungsi media massa lainnya (surat kabar dan radio siaran), yakni memberi informasi, mendidik dan menghibur dan membujuk.
Stasiun televisi pertama di Indonesia adalah TVRI, berdiri pada 24 Agustus 1962 yang merupakan satu-satunya stasiun televisi Pemerintah, pada 24 Agustus 1989 muncul stasiun televisi swasta pertama di Indonesia yaitu, RCTI dan kemudian hingga saat ini diikuti oleh banyak stasiun televisi swasta dan stasiun televisi lokal lainnya (Indosiar, SCTV, Trans TV, Trans 7, MNC TV, Global Tv, ANTV) untuk mengambil hati sekaligus memuaskan khalayaknya, berbagai stasiun televisi swasta memproduksi tayangan-tayangan yang dirasa akan banyak diminati oleh masyarakat. Berbagai macam program yang bertemakan edukatif, informatif, hingga menghibur pun ditayangkan. Selain televisi banyak media lain yang digunakan untuk mengakses berbagai tayangan 
seperti berita, film, gambar dan tayangan lainnya, media lain yang digunakan untuk manganalisis semiotika dalam tayangan bocah petualang ini adalah You Tube.

Link yang digunakan untuk mengakses tayangan bolang adalah "Bolang Edisi Di Lahat" atau di (https://www.youtube.com/watch?v=92zG x2Fchpg\&t=291s) yang di klik pada kolom bacaan You Tube pada Komputer atau Hp. You Tube adalah sebuah situs web berbagi video yang memungkinkan pengguna untuk mengunggah, menonton, dan berbagi video. You Tube menampilkan berbagai macam konten video buatan pengguna, termasuk klip film, klip TV, dan video musik. Selain itu ada pula konten amatir seperti blog video, video orisinal pendek, dan video pendidikan (Baskoro, 2009:58). Makna pesan yang terkandung dalam suatu tayangan, video atau film dapat dilihat dari penggunaan tanda, tanda atau simbol dalam ilmu komunikasi dapat kita pelajari dari ilmu semiotika.

Semiotika adalah ilmu yang mempelajari tentang suatu tanda (sign). Dalam Ilmu Komunikasi "tanda" merupakan sebuah interaksi makna yang disampaikan kepada orang lain melalui tanda-tanda. Dalam berkomunikasi tidak hanya dengan bahasa lisan saja namun dengan tanda tersebut juga dapat berkomunikasi. Ada atau tidaknya peristiwa, struktur yang ditemukan dalan suatu kebiasaan, semua itu dapat disebut tanda. Sebuah bendera, sebuah isyarat tangan, sebuah kata, suatu keheningan, gerak syaraf, peristiwa memerahnya wajah, rambut uban, lirikan mata dan banyak lainnya, semua itu dianggap suatu tanda (Zoezt, 2009 :18). Banyak makna semiotika yang belum diketahui orang dalam tayangaan bolang ini. Makna semiotika tergantung pada penggunaan tanda yang mungkin berupa suara individu atau bahasa yang di gunakan untuk membentuk kata-kata, gerakan tubuh yang dilakukan untuk menunjukkan sikap atau emosi, atau bahkan sesuatu yang umum berupa pakaian yang mereka kenakan dalam tayangan bolang tersebut.

Tayangan berasal dari kata tayang yang menurut kamus besar bahasa indonesia, tayang memiliki arti menayangkan suatu perbincangan mengenai masalah tertentu di televisi. Tayangan bolang merupakan satu dari tayangan televisi yang memiliki banyak manfaat bagi penonton karena tayangan bolang menyadarkan kembali orang untuk sama-sama melestarikan budaya indonesia yaitu gotong royong. Masyarakat Indonesia terkenal dengan sikap ramah, kekeluargaan dan gotong-royongnya di dalam kehidupan sehari-hari. Salah satu kegiatan gotong-royong yang sering dilakukan terdapat dalam masyarakat pedesaan, mereka biasanya bergotongroyong dengan mengerahkan tenaga tambahan dalam segala aspek kehidupan, terutama dalam pekerjaan bercocok tanam yang masih dilakukan secara tradisional.

Gotong-royong adalah kerjasama di antara anggota-anggota suatu komunitas. Sedangkan menurut asal kata, gotongroyong berasal dari kata gotong yang berarti "bekerja”, dan royong yang berarti "bersama” (Kamus Besar Bahasa Indonesia). Selanjutnya Koentjaraningrat (2008:20) membagi dua jenis gotongroyong, yaitu gotong-royong tolongmenolong dan gotong-royong kerja bakti. Kegiatan gotong-royong tolong-menolong adalah semangat yang diwujudkan dalam bentuk perilaku atau tindakan individu yang dilakukan tanpa mengharap balasan untuk melakukan sesuatu secara bersamasama demi kepentingan bersama atau individu tertentu. Gotong royong menjadikan kehidupan manusia Indonesia lebih berdaya dan sejahtera. Dengan gotong royong, berbagai permasalahan kehidupan bersama bisa terpecahkan secara mudah. Gotong royong pada zaman modern dan serba canggih pada saat ini dapat dikatakan sedikit mulai punah karena kemajuan teknologi yang sangat pesat. Tayangan bolang mengajakarkan kembali anak-anak untuk melestarikan 
budaya yang hampir punah ini yaitu gotong royong, karena dengan gotong royong akan menciptakan kebersamaan, kekompakan,dan juga kemudahan dalam suatu masyarakat.

Tayangan bolang banyak mengajarkan anak-anak pentingnya melestarikan budaya nilai gotong royong dalam kehidupan walaupun dengan semakin majunya teknologi anak-anak tidak boleh melupakan budaya yang sudah lama ada, dengan gotong royong anakanak akan mencintai budaya asal mereka berada yaitu budaya di Negara Indonesia, yang kaya akan nilai tradisi dan adat istiadat terutama gotong royong. Gotong royong dapat mempererat tali persaudaraan antar sesama individu oleh karena itu tayangan bolang banyak mengajarkan anak-anak untuk tetap berpegang teguh pada kebudayaan tempat mereka berasal dan melestarikan semua kebiasaan yang ada.

Tayangan bolang ini di bentuk sedemikian rupa yang menggunakan kreativitas tinggi untuk membuat anakanak tertarik melihatnya. Jam tayang bolang mulai dari jam 13.30 sampai dengan jam 14.30 yang tayang pada hari Senin-Jum'at. Tayangan bolang Penerima Anugerah Kebudayaan untuk Kategori Media dari Kementerian Pendidikan dan Kebudayaan RI untuk tahun 2016. Program acara "Si Bolang” (Bocah Petualang) telah 10 tahun memberikan hiburan dan pendidikan pada anak-anak Indonesia. Lima belas penghargaan dari kementerian, Komisi Penyiaran Indonesia (KPI), dan swasta telah diraihnya. "Si Bolang” tidak saja memperkaya program untuk anak-anak di televisi. Lebih dari itu, program ini ingin memberi ruang keadilan bagi anak-anak di daerah untuk turut mewarnai pendidikan kebudayaan di Indonesia. Juga mendekatkan anak-anak perkotaan dengan kekayaan alam, budaya, dan teman-teman sebangsa mereka (http://kebudayaan.kemdikbud.go.id).

Bolang (Bocah Petualang) adalah program petualangan anak di Trans7 yang menghadirkan perjalanan Si Bolang dari seluruh nusantara dalam memperkenalkan alam dan budaya di daerahnya masingmasing. Si Bolang di berbagai tempat di tanah air untuk memperlihatkan adat istiadat dan kebiasaan masyarakat, terutama anak-anak, dimana mereka berada. Acara yang bersifat mendidik ini akan memberikan anak-anak wawasan dan pengetahuan mengenai kebudayaan masyarakat Indonesia. Petualangan bolang saat berada di Kabupaten Lahat, Desa Lubuk Selo, Kecamatan Gumai Ulu, Sumatera Selatan. Akan mengingatkan anak-anak untuk sadar pentingnya melestarikan kebudayaan sendiri.

Lahat adalah sebuah Kecamatan yang juga merupakan Ibu Kota Kabupaten Lahat, Sumatera Selatan, Indonesia. Kabupaten Lahat merupakan satu komunitas masyarakat yang memiliki ciri khas unik mulai dari mulai bahasa, kebiasaan, anak-anak yang tidak takut untuk berpetualang di alam dan lain-lain. Kabupaten Lahat memiliki alam yang masih alami, dikatakan alami karena masih banyak pohon-pohon yang tumbuh subur dan rindang, hewan-hewan yang masih hidup bebas, dan masih banyak tumbuhantumbuhan yang dapat dijadikan obat karena masih sangat mudah untuk didapatkan. Kebiasaan masyarakat yang masih tradisional yaitu yang tidak merusak alam. Mereka menggunakan alat tradisional untuk menjaga Ekosistem di hutan, baik Ekosistem tumbuhan maupun hewan misalnya saat mengambil madu di hutan. Masyarakaat Lahat masih menggunakan asap sebagai alat untuk mengusir lebah, karena dengan menggunkan asap masyarakat tidak membunuh lebah tapi hanya mengusir lebah untuk pergi dari sarangnya, lebah tersebut masih tetap bisa hidup dan membuat sarang yang baru.

Sungai yang belum tercemar, alasannya karena masyarakat Lahat menggunkan alat tradisional saat ingin menangkap ikan di sungai, masyarakat Lahat menangkap ikan dengan 
menggunakan jaring, bukan dengan cara menyentrum atau menyebarkan obat kimia ke dalam sungai. Selain itu, masyarakat Lahat memiliki kebiasaan yaitu menggunakan bahasa tradisonal lahat saat berkomunikasi dengan masyarakat, mengarungi sungai dengan menggunkan rakit yang terbuat dari bambu, agar sungai tetap bersih, rumah-rumah panggung terbuat dari kayu dan bambu dibuat 2 tingkat, dibuat 2 tingkat karena untuk menghindari binatang buas masuk kedalam rumah. Mereka juga mengandalkan hasil dari hutan untuk digunakan sebagai obat, misalnya obat batuk dari batang angas-angas rimbo yang tumbuh subur di hutan. Masyarakat Lahat masih memegang teguh budaya gotongroyong sebagai alat untuk mempererat tali persaudaraan dan kekompakan. Oleh karena itu, Televisi Trans 7 tertarik untuk Syuting di Lahat karena alam yang masih asri, lokasi syuting yang banyak, sungai yang belum tercemar dan kebiasaan warga yang unik.

Pentingnya penelitian adalah untuk memahami nilai gotong royong yang terkandung dalam tayangan bolang yang menjadikan tayangan bolang sebagai tayangan yang banyak paling diminati oleh anak-anak, remaja bahkan juga dewasa. Untuk itu penulis tertarik menganggkat judul penelitian “Analisis Semiotika Nilai Gotong-royong Tayangan Bocah Petualang di Televisi Trans 7 (Analisis Semiotika Roland Barthes Dalam Tayangan Bolang Edisi Kabupaten Lahat Sumetera Selatan)”.

Tujuan Penelitian yang hendak dicapai dalam penelitian ini adalah Untuk mengkaji "Nilai Gotong Royong Pada Tayangan Bocah Petualang Edisi Kabupaten Lahat Sumatera Selatan (Analisis Semiotika Roland Barthes).

\section{METODE PENELITIAN}

Jenis penelitian yang digunakan adalah penelitian dengan metode analisis semiotik. Semiotik disebut sebagai ilmu tentang tanda. Semiotik merupakan studi mengenai arti dan analisis dari kejadiankejadian yang menimbulkan arti (meaning-producing event). Ilmu atau metode analisis .yang mengkaji tanda yang disebut semiotika pada dasarnya hendak mempelajari bagaimana kemanusiaan (humanity) memaknai halhal (things). Memaknai (to signify) dalam hal ini tidak dicampuradukkan dengan mengkomunikasikan (to communicate). Memaknai adalah bahwa objek-objek tidak hanya membawa informasi, dalam hal mana objek-objek tersebut akan berkomunikasi, tetapi juga mengkonstitusi sistem terstruktur dari tanda. Dipilih sebagai metode penelitian karena semiotik bisa memberikan ruang yang luas untuk melakukan interpretasi terhadap iklan sehingga pada akhirnya bisa didapatkan makna yang tersembunyi dalam sebuah iklan. Metode analisis pendekatan semiotik bersifat interpretatif kualitatif, maka secara umum teknik analisis datanya menggunakan alur yang lazim digunakan dalam metode penulisan kualitatif, yakni mengidentifikasi objek yang diteliti untuk dipaparkan, dianalisis, dan kemudian ditafsirkan maknanya.

\section{Objek Penelitian}

Tayangan Petualangan bolang(Bocah Petualang) membahas banyak hal misalnya makna kata, makna bahasa, makna symbol dan lain-lain atau arti dalam setiap tayangan yang ditayangkan pada 05 November 2016 di trans 7 dalam hal ini penulis menganalisis kata atau makna yang terkandung dalam acara tersebut.

\section{Teknik Pengumpulan Data}

Teknik pengumpulan data merupakan langkah yang sangat penting dalam suatu penelitian, karena sangat mempengaruhi hasil akhir penelitian dan kebenaran data yang didapat. Untuk mendapatkan data yang akurat, peneliti menggunakan teknik pengumpulan data dengan cara melalui dokumentasi. Dokumentasi adalah teknik pengumpulan 
data yang berdasarkan pada buku, foto, laporan penelitian, majalah, surat kabar, situs internet dan sebagainya yang dianggap relevan dalam penelitian ini. salah satu teknik pengumpulan data yang digunakan dalam penelitian peneliti dengan cara diambil dari Youtube, mendownload nya lalu menscreen shoot setiap scene dan yang ada dalam video tersebut.

Selain menggunakan sumber data berupa kata-kata/tindakan dan sumber tertulis, peneliti juga menggunakan sumber data berupa foto dan scereen shoot. Foto dan screen shoot sudah lebih banyak digunakan sebagai alat /untuk keperluan penelitian kualitatif. Foto menghasilkan data deskriptif yang cukup berharga dan digunakan untuk menelaah segi subjektif yang hasilnya dianalisis secara induktif (Lexy J. Moleong,2010: 157-160). Dokumentasi yang digunakan dalam penelitian ini adalah mengambil potongan gambar yang di scereen shoot yang terdiri dari beberapa scene dan lainlain.

\section{Teknik Analisa Data}

Miles dan Huberman (2005:23), mengemukakan bahwa aktivitas dalam analisis data kualitatif dilakukan secara interaktif dan berlangsung secara terus menerus sampai tuntas, sehingga datanya jenuh. Aktivitas dalam analisis data, yaitu : data reduction,data display, dan conclusion drawing/verification (Yopan, 2011:22).

Teknis analisis data adalah dengan menggunakan semiotika model Roland Barthes seperti, makna denotasi, makna konotasi dan mitos yang digunakan untuk memahami makna yang terkandung dalam setiap scene tayangan bocah petualang di televisi trans 7 (edisi tayangan bolang lahat sumatera selatan). Untuk menganalisis data dan temuan dalam tayangan bolang (bocah petualang) penelitian ini mengacu pada model analisis Roland Barthes (2008:16) Makna Denotasi, Makna Konotasi, Dan Mitos.
1. Denotasi :

Makna paling nyata dari tanda, apa yang digambarkan tanda terhadap sebuah objek.

2. Konotasi:

Bagaimana menggambarkan objek, ia bermakna subjektif juga intersubjektif, sehingga kehadirannya tidak disadari.

3. Mitos:

Merupakan produk kelas sosial yang sudah mempunyai suatu dominasi. Dalam dunia modern, mitos dikenal dengan bentuk Feminisme, Maskulinitas, Ilmu Pengetahuan, Dan Kesuksesan.

Dalam menganalisis penelitian penulis melakukan teknik analisis data yaitu dengan cara:

1. Penulis menonton tayangan bocah petualang di Youtube sebanyak 20 kali.

2. Mengumpulkan setiap potonganpotongan gambar yang ada nilai gotong royongnya.

3. Penulis akan menjabarkan dan menyimpulkan data yang diperoleh melalui video yang diputar melalui Youtube.

\section{HASIL PENELITIAN DAN PEMBAHASAN}

\section{Hasil Analisa Semiotika Tayangan Bolang Edisi Lahat Sumatera Selatan}

Tayangan yang menjadi penelitian penulis yaitu tayangan Si Bolang edisi Lahat Sumatera Selatan yang ditayangkan di Televisi. Namun karena di Televisi tidak ditayangkan lagi maka peneliti menggunakan You Tube untuk melihat kembali tayangan Si Bolang tersebut Tayangan yang berdurasi 20:30 (dua puluh menit tiga puluh detik). Tayangan ini berkisah mengenai petualangan seorang anak kecil yang di dalam tayangan tesebut banyak mengandung nilai-nilai gotong royong. Tayangan Bolang di lahat sumatera selatan berjudul "Sahabat Alam 
Dari Lubuk Selo”. Awal mula tayangan Bolang dimulai dari pertualangan bolang, kedua temannya bolang dan bapaknya Bolang ke hutan, mereka sama-sama mendayung rakit di sungai selangis menuju ke tempat untuk mengambil madu karena ibu dan kakak perempuan memesan madu.

Dengan menggunakan rakit akhirnya bapak Bolang dan temannya sampai ditempat mengambil madu. Tempat mengambil madu merupakan tebing madu yaitu tebing besar dan menjulang tinggi. Tebing tersebut dihuni lebih dari jutaan lebah sarang, sarang lebah banyaknya sekitar 30 sarang yang dapat mengahasilkan madu. Sesampai di tebing madu, bolang, bapaknya dan temannya bersiap-siap untuk mengambil madu, mereka bergotong royong. Bolang bertugas menghidupkan asap yang terbuat dari sabut kelapa, temannya bolang memegang peralatan seperti keranjang, dan bambu tempat untuk diletakkannya madu.

Sementara Bolang menghidupkan asap, bapak bolang bersiap-siap untuk menaiki tebing madu, karena Bolang dan temannya belum ahli maka Bolang dan temannya dilarang untuk memanjat tebing madu. Kemudian bapak Bolang bergegas naik ke tebing madu dengan menggunakan tangga yang terbuat dari bambu, merekapun bergotong-royong kembali. Bolang dan temannya bertugas untuk memegang tangga yang terbuat dari bambu agar bapaknya Bolang tidak jatuh. Bapak Bolang pun tiba diatas tebing dan mulai mengasapi sarang lebah dengan menggunakan asap dari sabut kelapa tadi, sementara Bolang dan temannya tetap memegang tangga yang terbuat dari bambu. Setelah lebah pergi dari sarang bapaknya Bolang dengan segera mengambil madu dengan menggunakan bambu yang dibuat menyererupai pisau. Setelah mengambil madu, bapaknya Bolang turun dan bolang juga temannya masih memegang tangga dari bambu agar bapaknya bolang turun dengan selamat.
Mereka pun pergi menepi untuk memasukkan madu pada tempat yang telah disediakan. Bapaknya Bolang bertugas memeras madu, sementara itu Bolang mengobati rasa sakit yang di alami bapaknya dengan menggunakan madu sebagai penawarnya. Karena, Mereka yakin bahwa madu merupakan obat tradisisonal bukan hanya untuk mengobati bengkak pada wajah tapi juga penyakit lainnya. Bolang dan temannya pun pergi bergegas untuk menyusul ibu dan kakaknya di tempat pemandian, tetapi ternyata Bolang dan temannya lupa membawa sabun untuk mandi. Bolang dan temannya tidak kehabisan akal, merekapun ingat bahwa dulu nenek Bolang pernah memandikan Bolang dengan Daun Tambora sebagai pengganti sabun. Mereka pun bergegas megambil daun Tambora, temannya Bolang bertugas untuk memegang tas dan teman lainnya bertugas memgang tangga agar Bolang tidak jatuh.

Setelah mengambil Daun Tambora Bolang dan temannya pergi ketempat ibu dan kakaknya berada. Sesampainya mereka di tempat ibu dan kakaknya, Bolang dan temannya memberikan madu pesanan ibu dan kakaknya. Lalu, Bolang dan temannya mandi di sungai dengan menggunakan Daun Tambora tadi sebagai pengganti sabun. Setelah mandi di sungai mereka pun melanjutkan perjalanan yaitu ke hutan untuk mengambil umpan ayam karena jagung sedang tidak musim. Mereka mengambil telur semut RangRang atau bisa disebut dengan kroto untuk umpan ayam. Sebelum megambil telur kroto ibu bolang memberikan abu untuk digosok di tangan dan kaki karena abu gosok dipercaya dapat membuat rang-rang tidak menggigit. Bolang, ibunya dan juga temannya pulang kerumah untuk memberi makan ayam, sesampai drumah Bolang, ibunya dan temannya memberi makan ayam dengan menggunakan kroto. Kroto mempunyai kandungan protein yang tinggi serta mudah dicerna oleh unggas dan dapat dipercaya dapat membuat ayam sehat dan lincah. Sore ini bapaknya Bolang ingin 
mengambil ikan disungai, tapi sebelum mengambil ikan disungai Bolang dan temannya terlebih dulu mengambil daun kelapa.

Bolang dan temannya membawa daun kelapa ke sungai. Sampai disungai bapak bolang dan temannya langsung menangkap ikan dengan cara memasang jaring. Dua temannya bertugas mengusik ikan dengan daun kelapa. Karena masyarakat setempat yakin ikan akan takut dengan gerakan daun kelapa sehingga ikan akan lari ke jaring. Setelah mendapatkan ikan mereka pergi kehutan untuk mengambil daun angas-angas rimbo dikarenakan temannya Bolang mengalami batuk. Masyarakat setempat yakin air yang berada dalam akar Angas-Angas rimbo dapat meredakan batuk setelah selesai mengambil batang angas-angas rimbo

Bolang dan temannya bergegas untuk pulang. Karena hari sudah sore, diperjalanan Bolang dan temannya tersesat tetapi mereka tidak kehabisan akal. Bolang terinagt akan perkataan kakeknya yang mengatakan bahwa membalik baju dapat membuat mereka tidak tersesat kembali. Akhirnya Bolang dan temannya berhasil untuk keluar dari hutan tetapi bukan dengan membalikkan baju tapi karena ada usaha. Membalikkan baju sebagai kepercayaan masyarakat Lahat saja.

\section{Hasil Penelitian}

Hasil Penelitian dibagi menjadi tiga scene yaitu scene 1 , scene 2 , dan scene 3

\section{Scene 1}

Momen Bolang, bapak Bolang dan Tiga teman Bolang di atas rakit.

\section{Denotasi}

Scene pertama diawali dengan gambar yang terlihat suasana saat Bolang, bapaknya dan temannya Bolang bersama-sama mendayung rakit di sungai. Bolang mendayung rakit di barisan paling depan menggunakan tas berwarna merah dan topi yang berwarna merah. Disekeliling bolang banyak pepohonan rindang. Sungai selangis yang mengalir dengan tenang. Terlihat temannya Bolang yang berada tepat di belakang Bolang memegang keranjang. Temannya Bolang yang mengenakan baju ungu celana biru terlihat melihat ke atas tebing. Sedangkan temannya Bolang yang mengenakan baju kuning celana hitam terlihat sedang menunjuk ke atas tebing. Mereka berjumlah 5 orang. Ekspersi wajah yang gembira hal ini terlihat dari senyum mereka. Bapaknya Bolang berada dibarisan paling belakang mengenakan baju merah lengan panjang celana hitam panjang dan memakai Kopiah, dan menggunakan bambu sebagai dayung yang lebih panjang dari bolang dan membawa juga peralatan kebun utuk mengambil madu seperti: keranjang, sabut kelapa, dan bambu untuk tempat madu.

\section{Konotasi \\ Konotasi yang ingin} disampaikan pada scene 1 gambar 1 ini adalah dengan menggunakan rakit mereka akan lebih cepat sampai di tempat mengambil madu. Rakit yang digunakan terbuat dari bambu, karena bambu merupakan tumbuhan yang mudah hidup jika diperkembangbiakan. Bambu juga sangat efisien dan ramah lingkungan karena pertumbuhan bambu sangat cepat dan menebang bambu tidak akan membuat hutan menjadi gundul. Bolang yang berada di barisan paling depan dengan mengenakan baju kuning menandakan bahwa Bolang adalah anak makmur. Baju yang dikenakan Bolang berwarna kuning memiliki arti kemakmuran oleh karena itu Bolang, temannya dan bapaknya dapat menjaga tali persaudarann dengan baik. Meskipun mereka hanya melakukan aktivitas sehari-hari didalam hutan. Karena itu mereka sangat menjaga kemakmuran dan ekosistem hutan. Terlihat Bolang sedang memegang bambu untuk mendayung rakit. Bambu tersebut lebih pendek daripada bapaknya Bolang karena bolang masih anak 
kecil dan jika memakai bambu panjang tentu Bolang akan kesulitan. Begitupun dalam kehidupan segala sesuatu harus sesuai dengan kemampuan karena jika melebihi porsi yang sudah ditentukan maka akan mengalami kesulitan. Tas dan topi yang digunakan Bolang berwarna merah. Merah artinya berani yang berarti seorang anak yang berani dilihat dari perjuangan Bolang untuk membantu bapaknya. Bolang mendayung rakit disungai padahal sungai berbahaya bagi anak kecil karena bisa hanyut, tenggelam ataupun diserang buaya. Tetapi, dengan adanya kekompakan mereka bersama-bersama melewati sungai tersebut. Temannya yang berada di barisan kedua dengan mengenakan baju merah, coklat dan kuning adalah orang yang membantu Bolang berpetualang mereka menjelajah hutan bersama-sama.

Mereka juga memiliki tugas, ada yang bertugas memegang keranjang sebagai tempat untuk meletakkan temuan/hasil mereka seperti madu ataupun ikan. Ada juga teman yang bertugas untuk menunjuk jalan, karena Bolang dan bapaknya hanya bisa fokus untuk menjaga keseimbangan rakit yang mereka gunakan. Selain itu, menggunakan rakit merupakan alat Transportasi masyarakat lahat untuk mencapai tujuan yang mereka inginkan. Dalam hal ini mereka bergotong royong dalam mencapai suatu tujuan karena dengan gotong royong mereka akan lebih mudah sampai di tempat tujuan mereka. Pada saat Bolang mendayung rakit di barisan paling depan, temannya Bolang membantu untuk memegang peralatan kebun tempat nanti madu diletakkan. Bapaknya Bolang bertugas untuk mendayung di bagian belakang. Menggunakan

\section{Scene 2}

Momen Sebelum Mengambil Madu

\section{Denotasi}

Terlihat Bolang bersama bapak Bolang dan temannya membantu bapaknya Bolang untuk mengambil madu. Bapaknya Bolang terlihat sedang memegang Asap dari sabut kelapa. Teman Bolang menyandang keranjang yang tebuat dari Anyaman Bambu. Kemudian, mereka bersiapsiap untuk mengambil madu. Tempat pengambilan madu berada di atas tebing yang berdinding batu dan sangat tajam. Sekeliling tebing banyak ditumbuhi rumput-rumput hijau dan ada sebilah bambu panjang yang digunakan sebagai tangga untuk memanjat tebing

\section{Konotasi}

Terlihat Bolang dan bapaknya tiba ditempat mengambil madu. Sesampainya di tempat mengambil madu, bapaknya Bolang mempersiapkan peralatan mangambil madu. Peralatan yang digunakan saat mengambil madu adalah berupa asap dari sabut kelapa. Asap dari sabut kelapa adalah alat yang digunakan untuk membuat lebah pergi dari sarangnya dan membuat lebah jinak. Tetapi, asap tersebut tidak akan membuat lebah mati jadi lebah tetap bisa hidup dan membuat sarang yang baru. Tempat mengambil madu berada diatas tebing yang berdinding batu dan tajam. Tempat seperti ini menandakan bahwa tempat tersebut masih sangat berbahaya dan beresiko tinggi. Akibat yang ditimbulkan sangat Fatal yaitu bisa cacat atau meninggal apabila melakukan kesalahan. Kemudian, saat ingin mengambil madu, Bolang menghidupkan asap yang terbuat dari sabut kelapa. Asap tersebut digunakan sebagai alat untuk mengusir lebah dari sarangnya dan membuat lebah menjadi jinak dan juga tidak menggigit. Tetapi, saat mengambil madu disekeliling tebing banyak ditumbuhi Pohon-Pohon. Pohonpohon tersebut menandakan bahwa 
tempat tersebut sangat subur dan sejuk. Hal ini disebabkan karena Pepohonan yang tinggi akan menghalangi sinar matahari secara langsung jadi, Pohon tersebut sangat berguna bagi kelangsungan hidup Tumbuhan dan juga Hewan.

Visual Moment Bapaknya Bolang Turun Dari Tebing

\section{Denotasi \\ Moment ketika bapaknya}

Bolang sedang turun dari atas tebing dengan membawa keranjang. Bapak bolang turun dengan perlahan. Sementara, Bolang dan temannya menunggu dibawah sambil memegang tangga dan memperhatikan bapak Bolang yang sedang turun.

\section{Konotasi}

Konotasi yang ingin

disampaikan pada scene 2 adalah saat ketika mengambil madu diatas tebing bapaknya Bolang turun dengan menggunakan tangga yang di pegang oleh Bolang dan juga teman Bolang. Tangga yang sedang dipegang menandakan bahwa agar seseorang yang sedang turun tidak tidak terjatuh, dan dapat turun dengan selamat. Saat turun bapaknya Bolang membawa keranjang. Keranjang menandakan bahwa dengan keranjang seseorang dapat meletakkan barang atau juga yang lainnya. Hal tersebut seperti yang dilakukan oleh bapaknya Bolang keranjang yang dibawa turun bapaknya bolang merupakan keranjang tempat madu. Bapak bolang turun secara perlahan hal ini menandakan bahwa bapak Bolang sedang turun dengan Hati-Hati agar tidak melakukan kesalahan sehingga dapat menyebabkan bapak Bolang jatuh.

Visual Moment Bolang Mengoleskan Madu Di Mata Bapaknya

1. Denotasi

Moment ketika Bolang sedang mengoleskan madu dibagian Mata yang sebelah Kanan tepatnya di kelopak Mata bapak Bolang yang bengkak akibat tersengat Lebah. Madu tersebut dipercaya dapat mengobati bengkak yang ada pada mata bapaknya.

2. Konotasi

Konotasi yang ingin disampaikan pada scene 2 adalah ketika Bolang mengoleskan madu di Mata sebelah kanan bapaknya yang bengkak akibat tersengat Lebah. Madu yang dioleskan pada mata bapaknya yang bengkak menandakan banyak sekali manfaat madu yang baik untuk Obat-Obatan dan juga kesehatan.. Mengoleskan madu kewajah bapaknya yang bengkak merupakan tanda sayang dan perhatian juga keperdulian seorang anak kepada bapaknya yang sedang sakit.

\section{Scene 3}

Moment Bolang Mengangkat Tangga Mengambil Daun Tambora

\section{Denotasi}

Moment ketika Bolang dan temannya bersama-sama mengangkat tangga dari bambu. Di sekitar bambu yang mereka angkat, ada Rerumputan Ilalang yang tinggi. Tangga tersebut digunakan untuk mengambil daun tambora diatas tebing. Daun tambora tersebut akan digunakan sebagai pengganti sabun.

2. Konotasi

Konotasi yang ingin disampaikan pada scene 3 adalah ketika Bolang dan temannya mengangkat tangga untuk mengambil Daun Tambora di atas tebing. Tangga merupakan alat yang digunakan untuk memanjat. Tangga tersebut digunakan untuk mengambil Daun Tambora.

Daun Tambora menandakan bahwa Daun Tambora tersebut dapat digunakan sebagai pengganti sabun. Daun Tambora merupakan tumbuhan yang dimanfaatkan orang zaman dahulu sebagai pengganti sabun karena Daun Tambora memiliki banyak busa dan dapat membuat tubuh menjadi bersih. 
Visual Moment Bolang Mengambil Daun Tambora

\section{Denotasi}

Moment ketika Bolang mulai memanjat tangga untuk mengambil Daun Tambora di atas tebing. Posisi Daun Tambora yang berada diatas tebing perlu menggunakan tangga untuk mengambilnya. Di sekitar Tumbuhnya Daun Tambora terdapat Rumput yang tumbuh dengan subur dan panjang. Panjang rumut kurang lebih satu meter.

2. Konotasi

Konotasi yang ingin disampaikan pada scene 3 adalah ketika Bolang yang memanjat tangga menandakan bahwa Bolang sedang memanjat tangga untuk Mengambil Daun Tambora yang ada diatas. Tempat Bolang mengambil Daun Tambora sangat lah berbahaya karena terlihat dari tebing yang berbatu dan juga runcing tajam. Sekeliling tebing tempat bolang mengambil Daun Tambora dikelilingi pohon dan rumput ilalang. Rumput ilalang yang berukuran panjang menandakan bahwa tempat tersebut sangat rawan bahaya karena rumput yang panjang tempat binatang berbisa bersembunyi.

Visual Moment Bolang Turun Dari Atas Tebing

\section{Konotasi}

Moment Bolang yang sedang turun karena sudah selesai mengambil Daun Tambora di atas tebing. Terlihat Bolang yang turun dengan perlahan dan Saat ketika Bolang hendak turun, temannya Bolang memegang tangga.

\section{Denotasi}

Konotasi yang ingin disampaikan pada scene 3 adalah yang ketika Bolang turun dari atas tebing dan temannya memegang tangga. Saat Bolang turun dari atas tebing menandakan bahwa bolang sudah selesai mengambil Daun Tambora. Bolang yang turun dari tangga dengan perlahan menandakan bahwa bolang sedang berhati-hati karena akan sangat berbahaya bagi keselamatan Bolang apabila samapai terpeleset dari tangga. Sedangkan, ketiga temannya memegang tangga saat bolang turun menandakan bahwa mereka perduli dengan keselamatan Bolang sahabatnya.

Visual Moment sebelum mengambil telur kroto.

1. Konotasi

Moment ketika Bolang, ibunya, dan temannya berjalan di hutan, Menuju ke lokasi tempat mengambil telur Semut Rang-rang (kroto). Bolang dan temannya sedang melihat kearah kanan dan kiri. Sekitar tempat mereka mengambil kroto di tumbuhi berbagai macam tumbuhan yang tumbuh subur. Banyak rerumputan yang tingginya hampir Dua Meter.

\section{Denotasi}

Konotasi yang ingin disampaikan pada scene 4 adalah ketika Bolang, ibunya dan temannya berjalan di hutan sebelum mengambil telur Semut RangRang (kroto). Berjalan di hutan menandakan bahwa mereka sedang menuju ke tempat mengambil telur semut Rang-Rang. Terlihat ibunya bolang menemani Bolang berjalan di hutan bersama-bersama. ditemani orang dewasa menandakan bahwa seorang ibu sedang melindungi anaknya dari bahaya yang mengancam. Selain itu, akan mempererat hubungan antara ibu dan anak. Terlihat juga saat Bolang menoleh kekiri dan kekanan menandakan bahwa mereka sedang melihat keberadaan semut Rang-Rang. Disekeliling tempat mereka berjalan banyak ditumbuhi pepohonan yang rindang menandakan bahwa hutan tersebut masih asri dan alami.

Visual Moment mengoleskan abu di tangan dan kaki.

1. Konotasi

Moment ketika Bolang, temannya dan ibunya mereka bersamasama memakai abu ditangan dan kaki. Terlihat juga banyak pohon yang rindang disekitar mereka. Tempat Abu yang digunakan terbuat dari batok kelapa da abu tersebut terbuat dari kayu bakar. Serta ibunya Bolang yang 
berpakaian mengenakan kain di kepala dan pinggangnya sambil meyandang keranjang.

\section{Denotasi}

Konotasi yang ingin disampaikan pada scene 4 adalah ketika Bolang, ibunya dan temannya bersama-sama mengoleskan abu di tangan dan kaki masing-masing. Mengoleskan abu menandakan bahwa mereka menginginkan kaki dan tangan mereka tidak digigit oleh semut rang-rang. Menurut kepercayaan masyarakat Lahat, Abu yang digunakan atau dioleskan di bagian tubuh sebelum mengambil kroto adalah agar semut menjadi jinak dan tidak menggigit. Selain itu, Abu juga di siramkan ke sarang semut rang-rang. Abu yang digunakan tidak sampai membuat semut mati tetapi hanya membuat semut pergi dan semut tetap bisa membuat sarang yang baru. Tujuan mengoleskan debu pada tangan dan kaki adalah agar semua yang berada di tempat mengambil kroto tidak di gigit semut dan apabila satu orang digigit maka semuanya akan di gigit semut. Karena Abu tidak begitu bertahan lama dan tidak mengandung bahan berbaya. sehingga aman digunakan untuk semua orang. Jadi, Bolang, ibunya dan temannya akan merasa adil dan tidak di beda-bedakan satu sama lain. Pakaian yang dikenakan oleh Ibu bolang menandakan Bahwa pakaian tersebut ciri Khas masyarakat Lahat saat pergi ke hutan atau kebun.

\section{Visual Moment Saat Memberi}

\section{Makan Ayam.}

\section{Denotasi \\ Moment ketika Bolang dan} temannya memberi makan ayam di halaman depan rumah Bolang. Disekitar halaman rumah Bolang dikelilingi pepohonan rindang dan hijau. Mereka bersama-sama memberi makan ayam yang berada di dalam keranjang dengan menggunakan telur semut Rang-rang (Kroto). Ayam yang ada di bawah keranjang berjumlah dua ekor dan ayam tersebut merupakan ayam kampong.

2. Konotasi
Konotasi yang ingin disampaikan pada scene 4 adalah ketika Bolang dan temannya bersamasama memberi makan ayam. Terlihat ketika Bolang dan temannya memberi makan ayam. Mereka memberika makan ayam di dalam suatu sangkar. Sangkar menandakan tempat ayam berada atau tempat ayam dikurung. Tanah luas tempat Bolang dan temannya memberi makan ayam adalah menandakan bahwa mereka sedang berada di halaman rumah. Tujuan memberikan makan ayam dengan kroto bersama-sama adalah untuk mempererat hubungan pertemanan karena dengan hal tersebut ikatan pertemanan akan semakin kuat. Menjaga kekompokan dan kepercayaan antara satu sama lain. Kroto yang diberikan kepada ayam diyakini dapat membuat ayam sehat dan kuat. Oleh karena itu, jika melihat pertumbuhan ayam yang sehat dan kuat karena usaha bersama akan membuat hati senang dan bangga karena usaha yang dilakukan bersamasama tidak sia-sia.'Ayam yang diberi makan oleh Bolang dan temannya merupakan Ayam kampung yang menandakan bahwa ayam kampung adalah Ayam khas orang yang tinggal di suatu perkampungan. Karena, Ayam kampung dapat hidup dengan mudah dan tidak perlu memerlukan makanan khusus seperti ayam Potong dan ayam lainnya.

Visual Moment Membawa Pelepah Daun Kelapa Ke Sungai

\section{Denotasi}

Moment Bolang bergotong royong mengangkat Daun Kelapa. Disekitar tempat tumbunya pohon kelapa dikelilingi oleh Pepohonan Rindang. Pohon yang tumbuh sekitar pohon kelapa merupakan pohon yang dapat dipetik hasilnya seperti Pohon Kopi dan Pohon Coklat. Pelepah daun kelapa tersebut akan digunakan sebagai alat untuk menangkap ikan di sungai. 
2. Konotasi

Konotasi yang ingin

disampaikan pada scene 5 adalah ketika Bolang dan temannya bersamasama membawa pelepah daun kelapa ke sungai. Pelapah daun kelapa menandakan sebagai alat untuk sebagai alat menangkap ikan disungai. Pelapah daun kelapah adalah alat tradisional yang digunakan agar tetap menjaga Ekosistem sungai tetap bersih. Pohon yang tumbuh disekitar pohon kelapa seperti Pohon Kopi dan Pohon Coklat menandakan bahwa dengan mananam pohon tersebut mereka dapat memetik hasil yang diperoleh dari pohon tersebut. Pohon tersebut dapat menghasilkan Uang apabila sudah berbuah.

Visual Moment Bolang, Bapaknya Dan Temannya Menghalau Ikan Di Dalam Sungai

\section{Denotasi}

Moment Bolang dan temannya yang menggunakan Daun Kelapa untuk menghalau ikan menuju ke jaring. Disekitar tempat mereka menangkap ikan ditumbuhi banyak pohon tumbuh di pinggir sungai. Terlihat juga ekspresi bahagia mereka saat menghalau ikan. Ekspresi bahagia tersebut berupa senyum.

\section{Konotasi}

Konotasi yang ingin disampaikan pada scene 5 adalah ketika Bolang, bapaknya dan temannya menghalau ikan menggunakan Daun Kelapa di dalam sungai. Menghalau ikan menggunakan daun kelapa di dalam sungai menandakan bahwa mereka sedang berusaha untuk mencari dan mendapatkan ikan disungai. Mereka juga sedang berusaha untuk menghalau ikan menuju jaring yang sudah disediakan. Menggunkan Daun Kelapa akan membuat ikan tetap hidup dan dapat berkembangbiak kembali. Sehingga ikan tetap bisa hidup dan berkembang biak dengan baik di dalam sungai. Ekspresi berupa tersenyum menandakan bahwa mereka sangat berharap agar hasil yang diperoleh tidak mengecewakan dan banyak.

Visual Moment Mengumpulkan Hasil Tangkapan

\section{Denotasi}

Moment Bolang, temannya dan bapaknya mengumpulkan ikan hasil tangkapan di dalam jaring. Ikan hasil tangkapan mereka berupa ikan baung. Banyak hasil tangkapan mereka kurang lebih sekitar 10-15 ikan.

2. Konotasi

Konotasi yang ingin disampaikan pada scene 5 adalah ketika Bolang, bapaknya dan temannya mengumpulkan ikan hasil tangkapan. Ikan yang dimasukkan didalam jaring menandakan bahwa ikan itu adalah hasil tangkapan mereka. Ikan hasil tangkapan mereka adalah ikan baung. Ikan baung merupakan ikan yang hidup di sungai. Keberadaan ikan baung di sungai menandakan bahwa sungai tersebut masih alai dan belum tercemar oleh zat berbahaya seperti obat kimia. Untuk mendapatkan ikan Mereka harus menjaga kekompokan, keberanian, dan kepercayaan agar hasil yang diperoleh tidak mengecewakan. hasil tangkapan yang banyak akan membuat perasaan lega dan gembira. Hasil tangkapan tadi dimakan bersama-sama atau bisa juga harus dibagi rata agar tidak ada rasa cemburu dan iri dalam diri.

Visual Moment Mengambil Akar AngasAngas

\section{Denotasi}

Moment Bolang, temannya mengambil akar Angas-Angas rimbo di hutan. Bolang memgang pisau yang sangat tajam saat menebang akar Angas-Angas rimbo. Kemudian, Salah satu temannya Bolang sedang mengepalkan tangan dibawah dagu atau mulutnya dan salah satu lagi membantu Bolang untuk memegang 
akar Angas-Angas rimbo. Angasangas rimbo tumbuh menjalar di antara pepohonan di dalam hutan.

$\begin{array}{lll}\text { 2. Konotasi } & \\ \text { Konotasi yang ingin }\end{array}$ disampaikan pada scene 6 adalah ketika Bolang, temannya menebang akar Angas-Angas rimbo di hutan. akar Angas-angas rimbo diyakini dapat menyembuhkan batuk. Oleh karena itu, bolang dan temannya mencari akar Angas-Angas rimbo yang hidup dihutan, Agar temannya sembuh dari batuk.. Bolang yang sedang memegang pisau menandakan bahwa bolang akan menebang akar angas-angas rimbo. Angas-angas rimbo tumbuh di sekitar pepohonan di dalam hutan. Di dalam akar AngasAngas rimbo mengandung banyak air yang biasanya digunakan sebagai persediaan air saat berada di hutan dan juga bisa sebagai obat tradisional.

\section{Visual Moment Bolang Menuangkan Air}

Akar Angas- Angas Rimbo

\section{Denotasi}

Moment Bolang dan temannya menuangkan air akar Angas-Angas rimbo. Terlihat Banyak pohon tempat Batang Angas-angas Rimbo hidup. Terlihat temannya Bolang sedang memberikan air Angas-angas Rimbo kepada temannya dengan cara memasukkan air Angas-Angas rimbo ke dalam mulut.

2. Konotasi

Konotasi yang ingin disampaikan pada scene 6 adalah ketika Bolang dan temannya menuangkan air dari batang angasangas rimbo di mulut seorang temannya menandakan bahwa mereka perduli dengan temannya dan berharap bahwa temannya dapat sembuh. Akar Angas-Angas rimbo diyakini dapat menyembuhkan penyakit. salah satu penyakit yang dapat disembuhkan yaitu batuk. Kemudian, Ketika Bolang dan temannya mengobati batuk maka akan timbul rasa bangga dan senang karena melihat temannya akan menjadi sembuh.

Visual Moment Lupa jalan pulang

\section{Denotasi}

Momet Bolang dan temannya sedang melewati air terjun. Air tejun tersebut merupakan air curup buluh tujuh tingkat . disekitar tempat mereka berjalan dipenuhi oleh bebatuan yang besar dan banyak pohon-pohon yang tumbuh tinggi dan subur disekitar tempat mereka berjalan. Kemudia, saat mereka berjalan mereka memakai baju terbalik ketika ingin pulang kerumah.

\section{Konotasi}

Konotasi yang ingin disampaikan pada scene 7 adalah ketika saat ingin pulang Bolang dan temannya lupa jalan pulang menandakan bahwa mereka sedang tersesat. Lokasi tempat mereka tersesat sangat berbahaya hal ini dilihat dari bayaknya pohon-pohon yang tumbuh tinggi dan Batu yang berukuran besar. Pohon yang tinggi menandakan bahwa temapat mereka berada adalah didalam hutan yang masih sangat alami. Batu-batu besar menandakan bahwa tempat tersebut merupakan tempat yang rawan akan bahaya. Jik batu yang berukuran besar tersebut menggelinding ke arah mereka maka sangat sulit untuk bisa menyelamatkan diri karena batu yang sangat berat dan besar tidak sebanding dengan tenaga yang dimiliki Bolang dan temannya. Hal itulah yang membuat mereka harus cepet-cepat keluar dari hutan ketika tersesat. Ketika mereka tersesat, Merekapun berfikir jernih, tidak menyalakan satu sama lain melainkan sama-sama memikirkan solusi dan jalan keluar agar bisa keluar darii hutan. Dan akhirnya karena usaha dan kerja keras mereka menemukan solusi yaitu Mereka membalikkan baju dengan harapan agar bisa pulang kerumah sebelum waktu sore. Karena, jika kemalaman maka hutan akan gelap sehingga sangat sulit mencari jalan keluar ketika malam hari. Membalikkan baju diyakini dapat membuat seseorang menemukan kembali jalan keluar dan hal itulha yang dilakukan Bolang 
bersama temannya. Walaupun mereka sedang tersesat, mereka tetap menjaga kekompokan dan setia kawanan. Pada akhirnya mereka menemukan jalan keluar sebelum hari malam.

\section{PENUTUP}

Berdasarkan hasil analisa dan pembahasan yang dilakukan penulis sebagai berikut:

1. Makna Denotasi pada tayangan Bocah Petualang Edisi Kabupaten Lahat Sumatera Selatan adalah Lokasi tempat mereka syuting merupakan hutan yang masih alami terlihat dari banyaknya Pohon-Pohon hijau yang tumbuh tumbuh subur dan rindang. Sungai yang masih asri dan belum tercemar dilihat dari banyaknya ikan hasil tangkapan.

2. Makna Konotasi dalam tayangan Bocah Petualang Edisi Kabupaten Lahat Sumatera Selatan adalah menjelaskan bahwa anak-anak yang sangat berbakti kepada orang tuanya dan juga setia kawan. Dan terdapat nilai gotong royong hampir setiap scene yang ada di setiap kegiatan yang mereka lakukan.

3. Mitos dalam tayangan Bocah Petualang Edisi Kabupaten Lahat Sumatera Selatan adalah Asap yang dapat membuat lebah menjadi jinak dan tidak menggigit. Abu yang dapat membuat semut Rang-Rang menjadi jinak dan tidak menggigit. Dan Membalikkan baju yang dapat membuat seseorang menemukan jalan keluar saat tersesat. Mitos tersebut hanyalah kepercayaan yang dipercayai secara turun-menurun saja tetapi sebagai manusia kita boleh mempercayai nya boleh juga tidak.

4. Nilai gotong royong yang terkandung dalam tayangan Bocah Petualang Edisi Kabupaten Lahat Sumatera Selatan adalah Anak-Anak yang selalu bersama-sama saling tolong-menolong untuk menyelesaikan suatu pekerjaan secara bersama-sama.

\section{Saran}

Ada beberapa saran yang ingin penulis sampaikan mengenai tayangan ini, yaitu:

1. Saat menonton sebuah tayangan, anak-anak perlu pendampingan orang tua ketika menonton tayangan bolang. Karena, banyak mitos-mitos yang terdapat dalam tayangan Bolang. Sehingga, anak-anak tidak mudah terpengaruh oleh mitos-mitos yang ada dalam tayangan tersebut.

2. Disarankan kepada pihak trans 7 untuk lebih memperhatinkan waktuwaktu yang tepat untuk menayangkan tayangan Bolang agar anak-anak dapat menonton tayangan tersebut. Dan lebih kreatif lagi untuk menayangkan tayangan dengan episode-episode yang baru. Agar penonton tidak merasa jenuh dan bosan.

3. Untuk penelitian selanjutnya yang tertarik ingin melakukan penelitian yang sama, mungkin bisa menjadikan penelitian ini sebagai referensi dan dapat menelitinya dengan menggunakan metode dan yang lain agar hasilnya lebih luas lagi

\section{DAFTAR PUSTAKA}

Ardianto, Elvinaro. 2007. Komunikasi Massa Suatu Pengantar. Bandung: Simbiosa Rekatama Media

Badjuri, Adi. 2010. Jurnalistik Televisi. Yogyakarta: Graha Ilmu.

Barthes, Roland. 2008. The Semiotics Challenge. New York: Hill and Wang.

Berger, 2009. Tanda-Tanda Dalam Kebudayaan Kontemporer. Yogyakarta; Tiara Wacana.

Bogdan, R, dan Taylor, S. (2007). Kualitatif Dasar-Dasar Penelitian. (A. Khozin Afandi, Penerjemah). Surabaya: Usaha Nasional 
Griffin, EM. 2007. A First Look at Communication Theory sixth edition. New York: McGraw-Hill.

McLuhan, Marshal. 2003 Understanding Media : The Extension of Man. London \& NewYork : Gingko Press.

Moleong, Lexy J. (2007) Metodologi Penelitian Kualitatif. Bandung: Remaja Rosdakary Offset,

Jalaludin Rakhmat, M.Sc.2008. Psikologi Komunikasi. Bandung: PT. Remaja Rossdakarya.

----------, 2004. Metode penelitian Komunikasi. Bandung: Remaja Rosdakarya.
Sobur, Alex. 2007. Semiotika Komunikasi. Bandung: Remaja Rosda Karya.

----------, 2007. Analisis Teks Media. Bandung: Remaja Rosdakarya

Saussure, F. De. 2010. Pusat Binbang Bahasa Depdikbud. Jakarta: PT. Remaja Rossdakarya.

Sumbo, Tinarbuko. 2008. Semiotika Komunikasi Visual. Yogyakarta: Jalasutra.

Van Zoest. 2009. Semiotika: Tentang Tanda, Cara Kerjanya dan Apa yang kita Lakukan Dengannya. Jakarta: Yayasan Sumber Agung) -----, 2010. Interpretasi dan Semiotikadalam Panuti Sudjiman dan Aart van Serba -Serbi Semiotika. Jakarta: Gramedia Pustaka Utama 